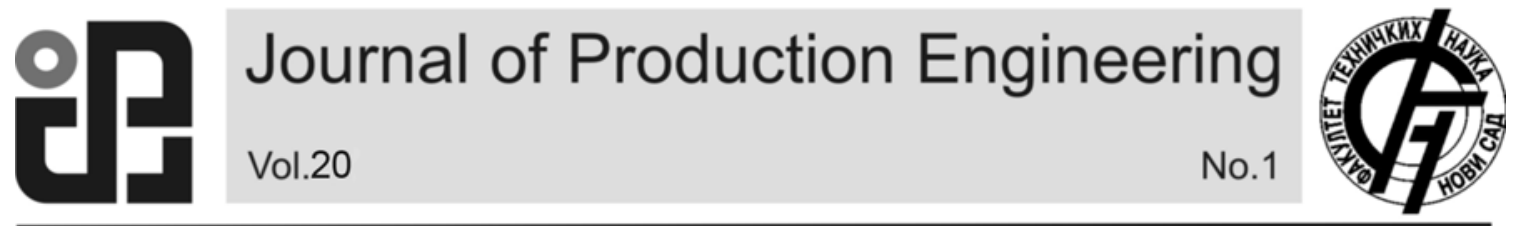

JPE (2017) Vol.20 (1)

Shuaib-Babata, Y. L., Adewuyi, R.A., Aweda, J. O.

Original Scientific Paper

\title{
EFFECTS OF THERMAL TREATMENT PROCESSES (TTP) ON SOME OF THE MECHANICAL PROPERTIES OF WELDED 0.165\% CARBON STEEL
}

Received: 15 March 2017 / Accepted: 19 April 2017

\begin{abstract}
One of the major causes of structural failure in service is attributed to failure in its parts, especially at the welded joints. Engineers and other users of low carbon steel tend to find solution to this problem by considering the application of Post weld heat treatment (TTP).The Microstructure and mechanical properties of heat-treated and untreated welded low carbon steel samples were determined. Simulation of the specimens was also generated using Autodesk Inventor Simulation CFD 2015 Application Software. The CFD model (simulation) showed clearly the visual style wireframe and shaded mesh (XY, and XZ planes and the temperature profiles for different passes), which is a veritable tool to evaluate residual stress that is likely to happen in real welding process. The results also revealed that better quality mechanical behaviour of welded low carbon steel is elicited by post-weld normalizing and annealing TTP.
\end{abstract}

Key words: welding, simulation, failure, microstructure and thermal treatment process

Uticaj procesa termičke obrade (TTP) na neke od mehaničkih osobina zavarenih $0,165 \%$ ugljeničnih čelika. Jedan od glavnih uzoraka loma u strukturi konstrukcije se pripisuje otkazu njegovih delova, posebno na zavarenim spojevima. Inženjeri $i$ drugi korisnici nisko ugljeničnih čelika teže da pronađu rešenje za ovaj problem a to je primena termičke obrade posle zavarivanje (TTP). Mikrostruktura i mehaničke osobine termički obrađenih $i$ netretiranih zavarenih uzoraka čelika sa niskim sadržajem ugljenika su ovde pripremljeni. Za simulaciju uzoraka korišćena je simulacija izrađena u softveru Autodesk CFD 2015. CFD model (simulacije) je pokazao vizuelno jasnu konstrukciju rama $i$ mreže u (XY i XZ ravni i profil temperature za različite preseke), što je pravi instrument za određivanje zaostalih napona kao u stvarnom procesu zavarivanja. Rezultati su takođe otkrili da je bolji kvalitet $u$ pogledu mehaničkog ponašanja zavarenih nisko ugljeničnih čelika postignut posle normalizacije $i$ žarenja TTP zavara

Ključne reči: zavarivanje, simulacija, otkaz, mikrostruktura i proces termičke obrade

\section{INTRODUCTION}

Welding process is highly significant in production of tools, equipment and in other structural developments. Currently, the process is used for fabrication and construction of a variety of structures such as buildings, bridges, ships, offshore structures, boilers, storage tanks, pressure vessels, pipelines, automobiles and rolling stock [1]. As a result of the quest for materials that can perform such task at optimum efficiency, Metallurgist, Designers and Engineers have been forced to look into the ways of developing materials that will be able to suite specific engineering applications [2].

In welding, pieces to be joined (the work pieces) are melted at the joining interface and usually a filler material is added to form a pool of molten material (the weld pool) that solidifies to become a strong joint. The weld metal and the base metal close to the fusion zone are subjected to cyclic thermal loads during the welding process [3]. To certain degree, the materials in the fusion zone do undergo plastic deformation during the process. This may lead to work hardening at the zone, and formation of residual stress may also occur. Dean et al. is also of the opinion that welding residual stress may also occur in Heat affected zone (HAZ), which may accelerate corrosion attack and cracking propagation [3]. Poor or incorrect welding procedure may also produce imperfections, stress corrosion cracking, fatigue failure, or brittle failure that may eventually lead to premature failure at the welded joint while in service.

One of the major causes of structural failure in service is attributed to failure in its parts, especially at the welded joints. This phenomenon is peculiar to the components made with low carbon steel (NST 44-2). High residual stress and distortion in materials that are attributed to welding process cannot be neglected as contributing factors to structural failure due to welded joint failure. Common leading structural failures are classified into four [4], in which defective materials which occur during manufacturing process is one of them. Inferior constructional material is also identified by Bright Hub Engineering [5] as part of the causes of structural failure.

Heat treatment is the term used to alter or improve some properties of materials by heating to certain temperature, holding at that temperature and cool appropriately to ambient temperature [6]. The treatment is an easiest process of improving material properties. It is an important operation in the final fabrication process of many engineering components [7]. Post weld heat treatment (TTP), is a procedure that is used to influence the structure and the properties obtained in 
the weld zone and in the heat affected zone (HAZ) [8]. Effective post weld heat treatment has been a the primary means by which welded zone, heat affected zone properties and minimum potential for hydrogen induced cracking are corrected [9]. Only by heat treatment is it possible to impart high mechanical properties on steel parts and tools for sophisticated applications [10]. Among other factors that influence the need for TTP are dimensions, joint design, welding parameters and the likely mechanism of failure [11]. Hard microstructure of the Heat affected zone (HAZ), which is also another known factor responsible for the property deterioration of weld and cold cracking susceptibility are preventable by pre and post weld heat treatment [12]. This was concluded while searching the methods for predicting maximum hardness of Heat Affected Zone and selecting necessary preheat temperatures for steel welding [13]. Due to failure at welded joints, Engineers and other users of low carbon steel tends to find solution to this problem, hence the application of Post weld heat treatment (TTP) is considered.

Defectiveness or inferiority of a material, either in raw or as result of fabrication process, nor through thermal treatment could be known through better understanding of the material's properties. More so, the effective usage of materials or effectiveness of any materials process can be realized only when an engineer fully understands the various properties of materials. This can be obtained through mechanical testing. It is also necessary to note that in multi-pass welding, the welded materials' properties at the fusion zone and Heat affected zone (HAZ), such as yield strength and hardness depend on the welding process [3]. Therefore, there would be need for better understanding of the real situation of the welded joints as result of welding processes and pre/post thermal treatment through knowledge of the materials' properties, which is the basis of this study. Mechanical tests such as tensile test, hardness test and microstructure observation would reveal improved properties of the materials that could reduce failure at Welded joints.

\section{MATERIALS AND METHODS}

A Commercial steel of $14 \mathrm{~mm}$ thickness was obtained for this study, being a material universally used by local fabricators and Engineers.

\subsection{Chemical Composition of the Test Specimens}

The chemical composition of the sample was obtained using an Optical Emission Spectrometer (OES), MODEL JEOL JEM2100, for proper classification of the steel.

\subsection{Preparation of the Test Specimens}

The low carbon steel was cut into 40 pieces with dimension $100 \mathrm{~mm}$ by $50 \mathrm{~mm}$ by $14 \mathrm{~mm}$ and welded into 20 pieces with dimension $100 \mathrm{~mm}$ by $100 \mathrm{~mm}$ by $14 \mathrm{~mm}$ shown in Plates 1. For ease thermocouple placement on samples, $5.0 \mathrm{~mm}$ diameter hole was drilled and taped close to the upper edge of each of the samples, prior to welding operation, as shown in Plates
1. The thermocouple was used to measure temperature during welding process. Edge preparation was done for each pair of the specimens by chamfering one of the $100 \mathrm{~mm}$ by $14 \mathrm{~mm}$ faces of all the pieces to get Double$\mathrm{V}$ where the pairs were welded (Double-V-butt welded joint).The joint configuration considered for this type of design was Double-V-butt joint, achievement of the required static strength is a primary criterion in the selection of joint design. The two pieces to be joined (the workpieces) were melted at the joining interface (Double-V-butt joint) by the use of filler material (Olikon type of Electrode ø8mm (E6013) $\left(\mathrm{G}_{10}\right)$ added. The welding at assumed speed $15 \mathrm{~mm} / \mathrm{s}$ selected to form pool of molten material (the weld pool) at one pass on each side that solidifies to become a strong joint.

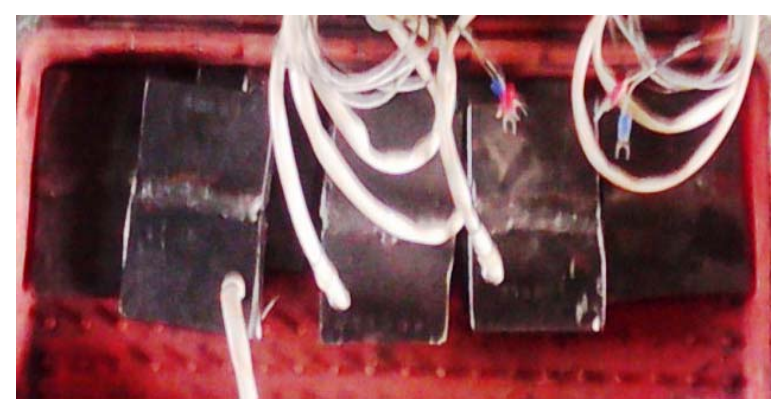

(a)

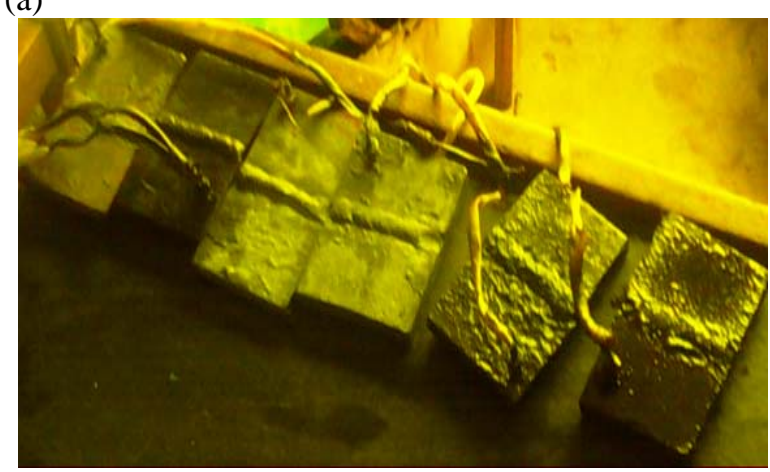

(b)

Plate 1. Welded specimens (a) before thermal treatment (b) after thermal treatment

\subsection{Simulation of the Test Specimens}

An Autodesk Inventor Professional Modeling Software was used to generate the 3D drawing (model) shown in Figure 1. Autodesk Inventor Simulation CFD 2015 Application Software was also used to show the heat distribution across the weld bead, Planes YZ, XZ and XY (shown in Figure 2), fully described in ShuaibBabata \& Adewuyi earlier study [14].

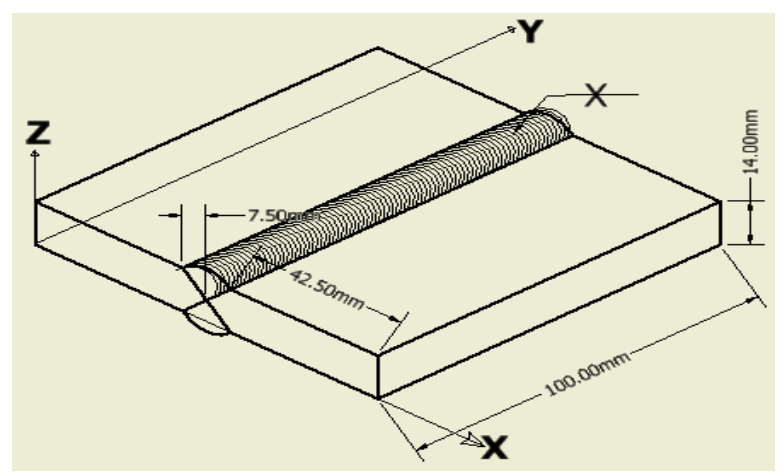

(a) 


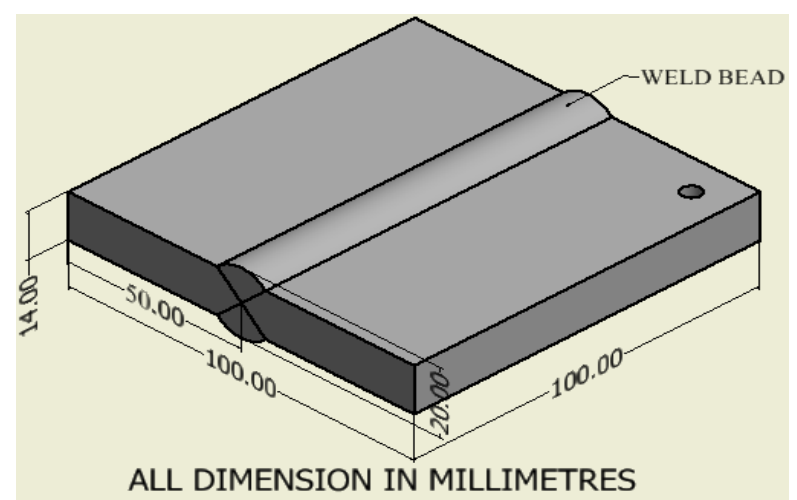

(b)

Fig. 1. 3-D Model of the Test Specimen Generated from Autodesk Inventor Professional Modeling Software,(a) Double-V-butt welded joint and (b) $5.0 \mathrm{~mm}$ hole drilled and taped respectively.

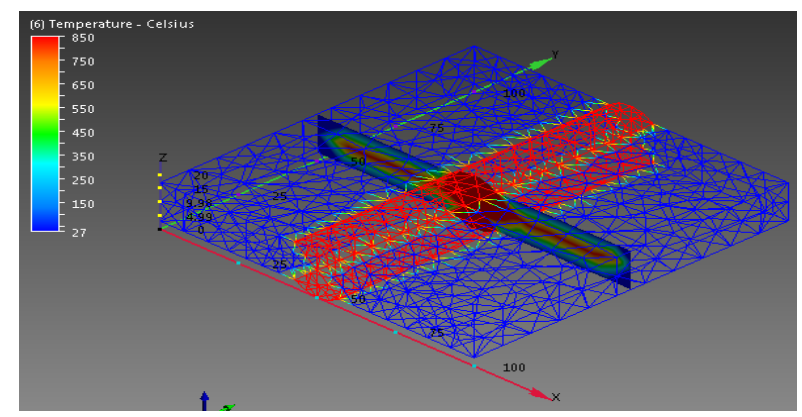

(a)

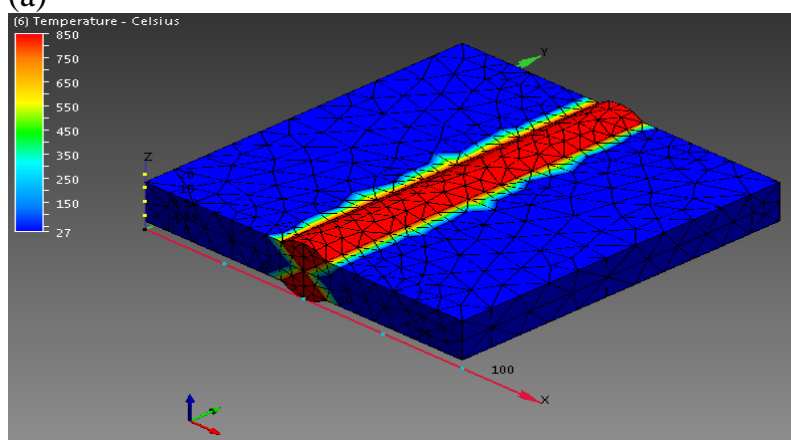

(b)

Fig. 2. Simulated Model of low carbon steel showing Haet Affected Zone and welded zone on the three Planes (YZ, XZ, XY) Using; Autodesk Inventor Simulation CFD 2015 Application Software; (a) Visual style -Wire frame and (b) Visual style-Shaded mesh.

\subsection{Thermal Treatment and Quenching}

Sequel to thermal treatment, Thermocouple of KType (Plat-inum Rhodium) (-30 to $+13700 \mathrm{C})$ were placed on each of the holes drilled on upper edge of the welded specimen, connected to the temperature controller to read the core temperature of the specimen while inside the furnace, as shown in Plates 1above.

A set of five standard specimens was annealed by heating to a temperature of $920^{\circ} \mathrm{C}$ in a furnace and cooled in the furnace environment to room temperature. The next set of five specimens were normalized by heating to a temperature of $920^{\circ} \mathrm{C}$ and held for about 20 minutes and allowed to cool naturally in air. A set of two standard specimens at a time was heated to temperature of $920^{\circ} \mathrm{C}$ and was allowed to homogenize at that temperature for 20 minutes and this was repeated for four different periods. After 20 minutes, the specimen was taken out of the furnace and directly quenched in different media (Tap Water, Palm oil, Quartz 5000 Total Engine oil and Groundnut oil) maintained at room temperature in the quenching tank. After thirty minute the specimen was taken out of the quenching tank and cleaned properly. The remaining two as-weld (untreated) specimens served as control.

\subsection{Mechanical tests}

\subsubsection{Hardness test}

Prior to the test, the specimens were grounded and polished. The hardness values of the specimens were obtained using software driven Optical Microscopy Machine by means of Brinell hardness tester in accordance with BS 240: 1986 and ASTM E10-15a standards $[15,16]$. The hardness was measured across the radial distance at 5 equal intervals on each specimen. The test was carried out five times and the average corresponding hardness values versus specimens obtained were documented graphically.

\subsubsection{Impact test}

The specimens were subjected to impact test on an Izod V-Notch impact testing machine shown in Plate 2. The specimens were prepared and notch at reference point and clamped at pendulum swinging axis waiting for external force. The pendulum of the machine was allowed to swing freely through a known angle, some energy was used to break the specimen, and the energy was recorded directly on the scale attached to the machine. The corresponding impact values versus specimens were plotted.

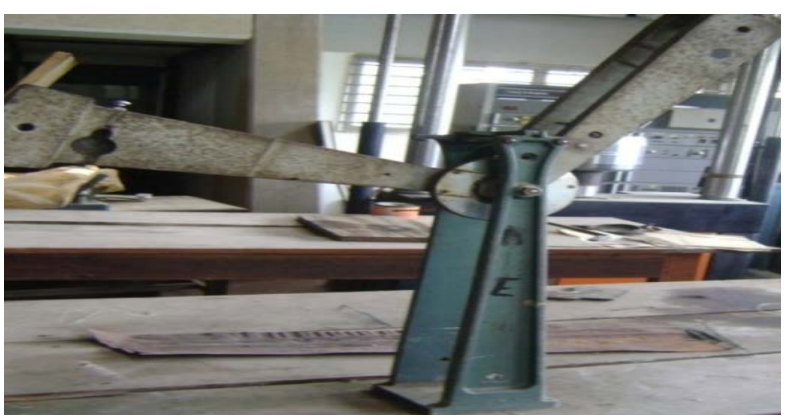

Plate 2. Izod Impact Machine

\subsubsection{Fatigue Test:}

Fatigue test was carried on all the samples using an Avery Denison Fatigue Tester shown in Plate 3. The corresponding values for each specimen were obtained and documented. The machine consist of an electric motor capable of running at $1,000 \mathrm{rev} / \mathrm{min}$, a large bearing whose purpose is to relieve the motor of the large bending moment which was applied to the specimen, collected and held the specimen and a rotating level arm, subjected to download force, in order to place specimen in a state of bending. The specimen was clamped into the machine, and loaded before switching on the machine. 


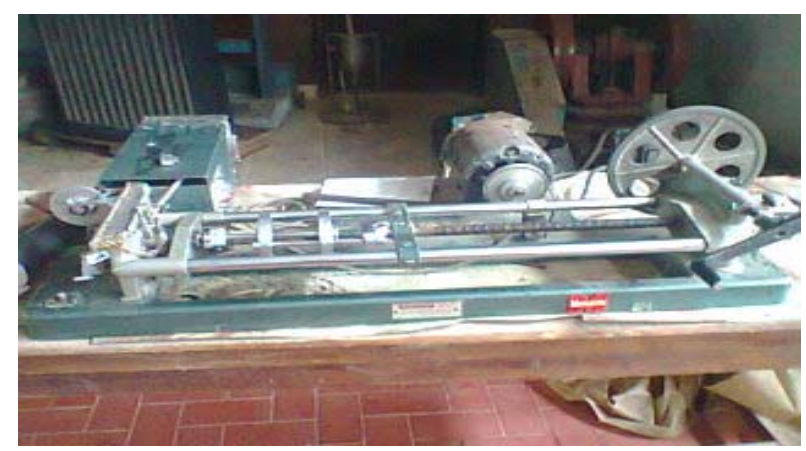

Plate 3. Avery Denison Fatigue Machine Tensometer.

\subsubsection{Tensile test}

The tensile specimens (heat treated and non-heat treated) were prepared as shown in Figure 3 and individually subjected to tensile forces on Computerized Universal Testing Machine (UTS), a Testometric Materials product (shown in Plate 4 below). The values of the tensile stress, tensile strain and energy (toughness) at yield, peak, and fracture for each specimen were obtained and documented from the system.

The results of the specimen's elemental chemical composition and that of standard low carbon steel obtained in a technical literature are presented in Table 1.

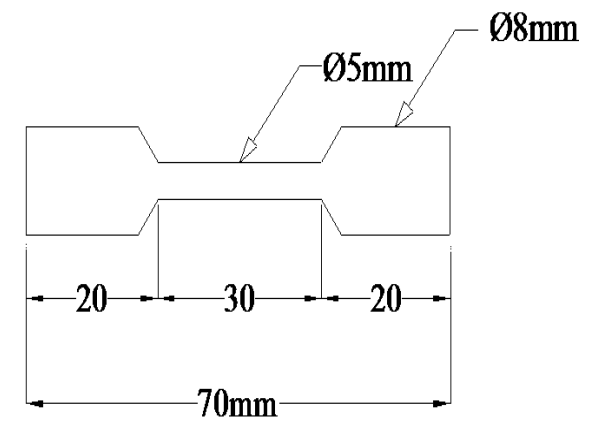

Fig. 3. Tensile Test Specimen

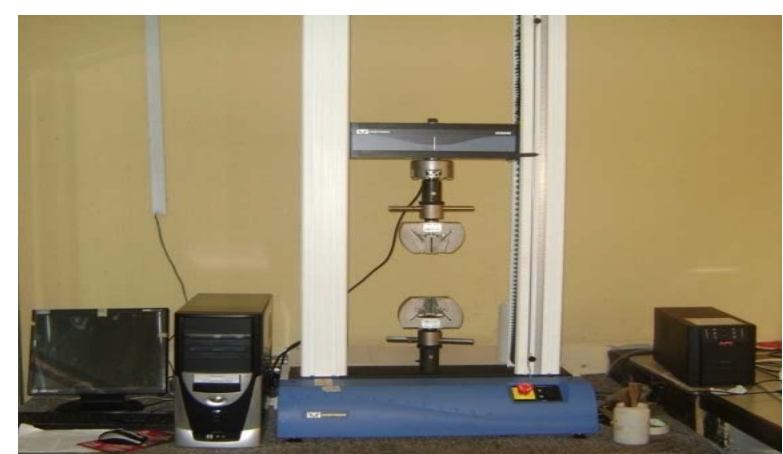

Plate 4.Computerized Universal Testing Machine(UTS)

\subsection{Microstructural Analysis}

The specimens were mounted in hot phenolic powder and were ground on a water lubricated hand grinding set-up of abrasive papers, from the coarsest to the finest grit sizes. Polishing was carried out on a rotating disc of a synthetic velvet polishing cloth impregnated with micron alumna paste. Final polishing was carried out with diamond paste. The specimens were then etched with standard $2 \%$ nital so as to reveal the ferrite grain boundaries. The optical microscopic examinations were carried out on a metallurgical microscope with magnification $40 * 16$ (shown in Plate 5). Low carbon steel has several structures such as ferrite, pearlite, and martensite depending on how the carbon is distributed in the material. Differences in microstructure are important because they can help to determine if a metal has been subjected to corrosive chemicals, is softer or harder at the surface, has been deformed, was welded properly, or has been overheated.

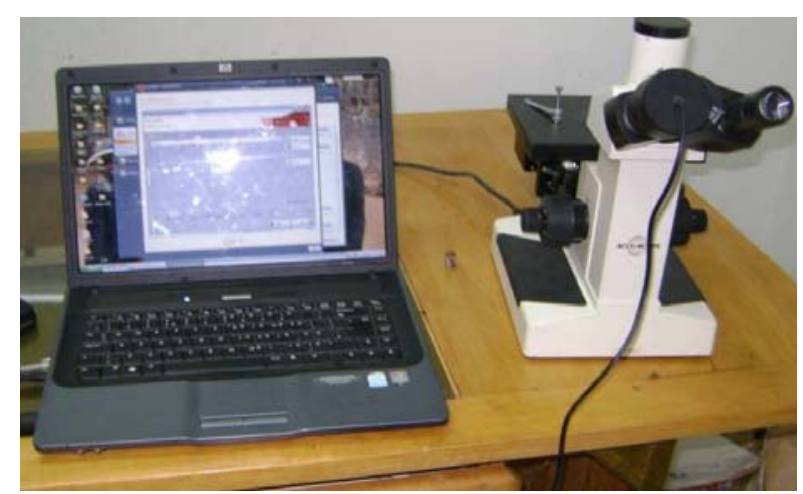

Plate 5. Microscope with Cam for microstructural analysis.

\section{RESULTS AND DISCUSSION}

\subsection{Chemical composition}

\begin{tabular}{|l|l|c|c|c|}
\hline Grade & $\begin{array}{l}\text { Colour } \\
\text { code }\end{array}$ & $\begin{array}{c}\% \\
\text { Weight } \\
\text { Carbon }\end{array}$ & $\begin{array}{c}\text { \% } \\
\text { Weight } \\
\text { Silicon }\end{array}$ & $\begin{array}{c}\text { \% } \\
\text { Weight } \\
\text { Manganese }\end{array}$ \\
\hline $\begin{array}{l}\text { NST } \\
\text { 44-2 [2] }\end{array}$ & Yellow & $\begin{array}{c}0.135 \\
-\end{array}$ & $\begin{array}{c}0.180 \\
-\end{array}$ & 0.40 \\
0.330 & 0.280 & 0.600 \\
\hline $\begin{array}{l}\text { NST } \\
\text { 44-2 }\end{array}$ & Yellow & 0.165 & 0.190 & 0.500 \\
\hline
\end{tabular}

Table 1. Chemical composition of low carbon steel sample as obtained using optical emission spectrometer.

The result revealed that the specimen possessed $0.165 \%$ of carbon, $0.19 \%$ of Silicon and $0.50 \%$ Manganese. The elemental composition of the specimen fell within the standard values for low carbon steel as shown in Table 1.

\subsection{Simulated Result of Heat Affected Zone on the three Planes (YZ, XZ, XY) using Autodesk Inventor Simulation CFD 2015 Application Software.}

The thermal simulation of heat affected zone and welded pool on low carbon steel showing the three Planes (YZ, XZ, XY) using Autodesk Inventor Simulation Computational fluid dynamics (CFD) 2015 Application Software in Figure 1b above helps to understand how the temperature distribution changes with time. This sort of information is useful for assessing thermal stresses which may lead to failure.

A heat-affected zone (HAZ) is the portion of the base metal that was not melted during brazing and cutting/welding process, but whose microstructure and 
mechanical properties were altered by the heat generated. This alteration can be detrimental, causing stresses that reduce the strength of the base metal, leading to catastrophic failures. The HAZ occurs inside the base metal and cannot be seen. The HAZ may need to be partially or completely removed (by grinding or some other process like heat treatment) before the metal part can be used.

The simulated results are also shown in Figures 4a, $4 \mathrm{~b}$ and $4 \mathrm{c}$ for YZ-Plane heat affected zone across the welded area, XZ-plane heat affected zone along the welded area and XY-plane heat affected zone on the welded area respectively. These figures are the same but show different views / planes of the graphical result of the simulation.

\section{YZ-Plane Heat Affected Zone across the Welded area}

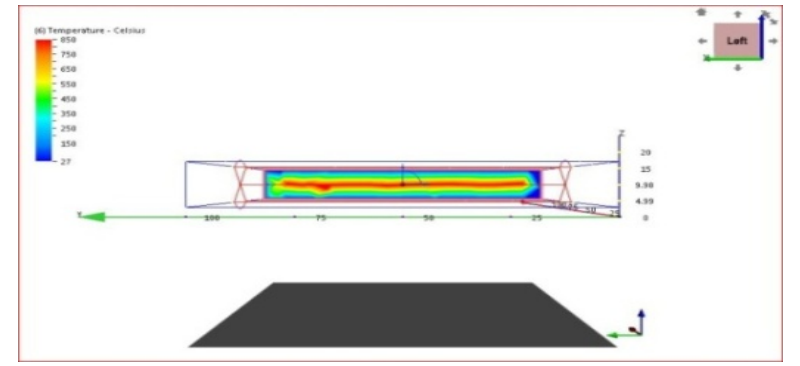

(i)

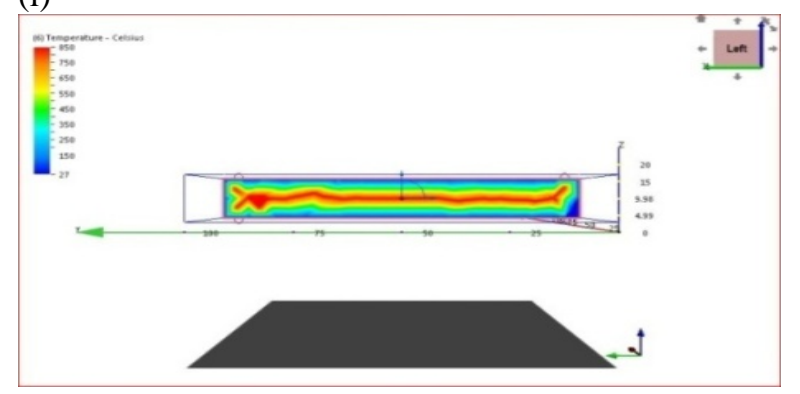

(ii)

Fig. 4a. Heat Affected Zone across the Welded area (i) YZ-Plane 61.00, 66.3, 7.00, (ii) YZ-Plane 10.6, 66.3,7.00.

Figures 4a (i) and (ii) indicate Heat Affected Zone on different coordinate points determined from the base metal to the weld metal viewed from YZ-plane $(100 \mathrm{x}$ $14 \mathrm{~mm})$. The microstructure of the center of heataffected zone (Reddish area) is completely different from the heat-affected zone (Yellowish, Greenish and Bluish area) to the edges of the plate. The effect of Heat Affected Zone decreases to the edges of the plate, Reddish area was greatly affected.

XZ-Plane Heat Affected Zone along the Welded Area

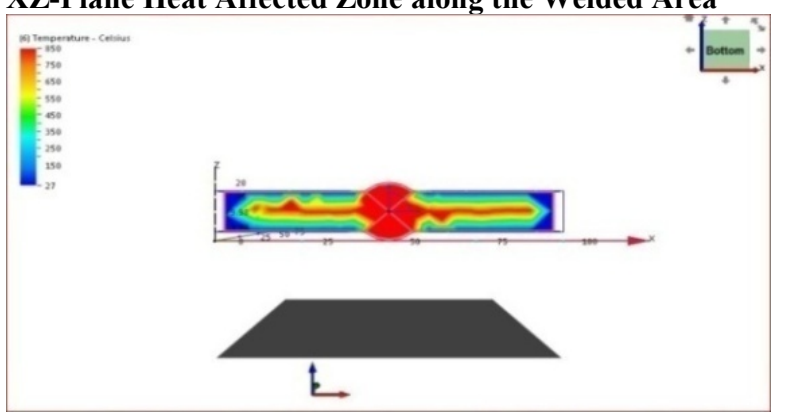

(i)

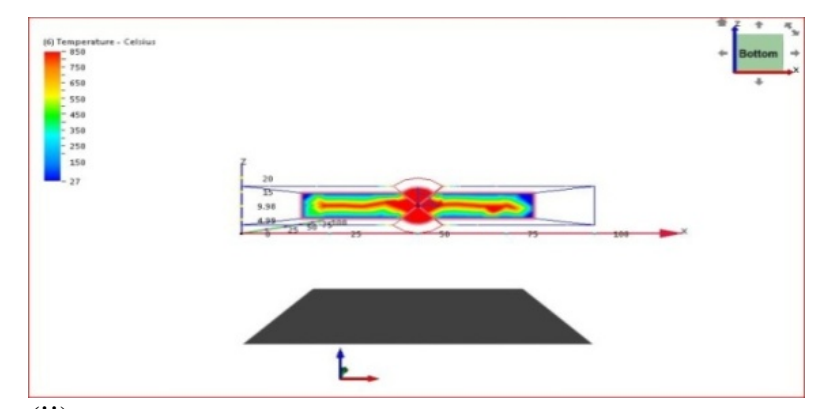

(ii)

Fig. 4b. Heat Affected Zone along the Welded Area (i) XZ-Plane 61.00, 66.3, 7.00 (ii) XZ-Plane 10.6, 66.3,7.00.

Figures 4b (i) and (ii) indicate Heat Affected Zone on different coordinate points determined from the base metal to the weld metal viewed from XZ-plane (100 x $14 \mathrm{~mm}$ ). The microstructure of the center of weld zone (Reddish area) is also completely different from the heat-affected zone (Reddish, Yellowish, Greenish and Bluish area) to the edges of the plate.The effect of the heat affected zone as shown in XZ plane view also decreases towards the edges of the plate.

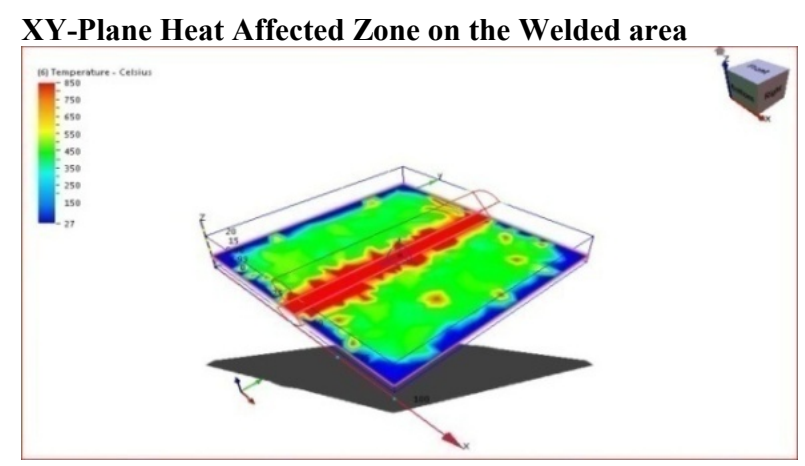

(i)

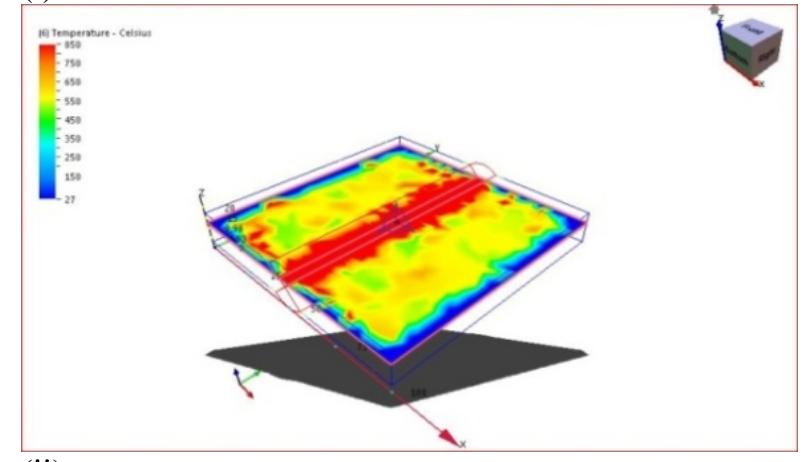

(ii)

Fig. 4c. Heat Affected Zone on the Welded area (i)XYPlane 61.00, 66.3, 7.00 (ii) XY-Plane 10.6, $66.3,7.00$.

Figures 4c (i) and (ii) indicate Heat Affected Zone on different coordinate points determined from the base metal to the weld metal viewed from XY-plane $(100 \mathrm{x}$ $100 \mathrm{~mm})$. The microstructure of the center of weld zone (Reddish area) is completely different from the heat-affected zone (Reddish, Yellowish, Greenish and Bluish area). The effect of Heat Affected Zone decreases towards the edges of the plate. 
Generally, the heat affected zone decreases as the colour of the affected area changes from ReddishYellowish-Greenish-Bluish area. That is, the heat affected zones concentrate more at the centre and decreases towards the edges of the plate. Hard microstructure of the Heat affected zone, (HAZ) is said to be responsible for the property deterioration of weld and cold cracking susceptibility and these are preventable by pre and post weld heat treatment [17].

The first and second passes profiles from CFD model are clearly shown in figures 5 and 6 .

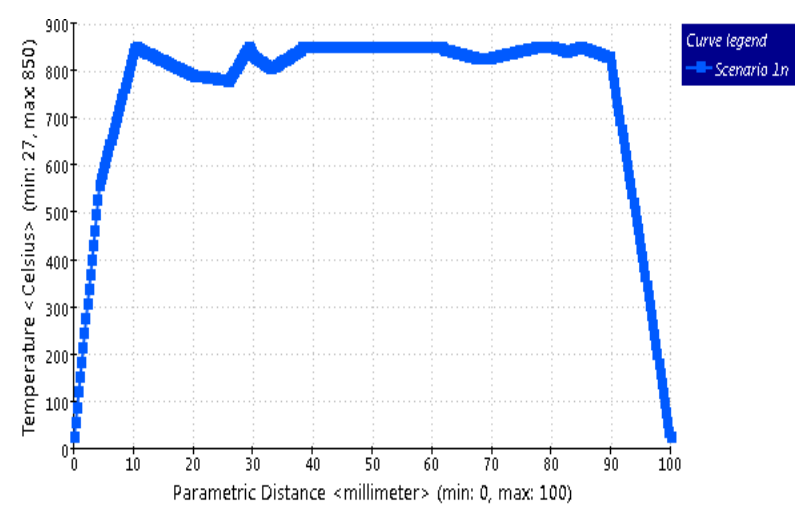

Fig. 5. Temperature Profile from CFD Model for the first pass

The welding temperature profiles from CFD model enhance better understanding of the temperature profile during welding process, which may assist to proffer solution to structural failure that may arise in the welded joints as result of welding residual stress. The temperature profile model as shown Figures 5 and 6 is a veritable tool to evaluate the welding residual stress that is likely to occur in practice (real welding process). According to Dean, et al.[3], a good prediction and efficient evaluation of welding residual stress are necessary, since welding residual stress depends on welding process parameters like heat input, number of weld pass, among others. These parameters are clearly revealed through the simulation (Figures $4-6$ ). The welding temperature profiles will assist both Engineers and Fabricators to put in place necessary measures required to afford over-heating, structural defects that may result from the welding process and other forms of structural failures.

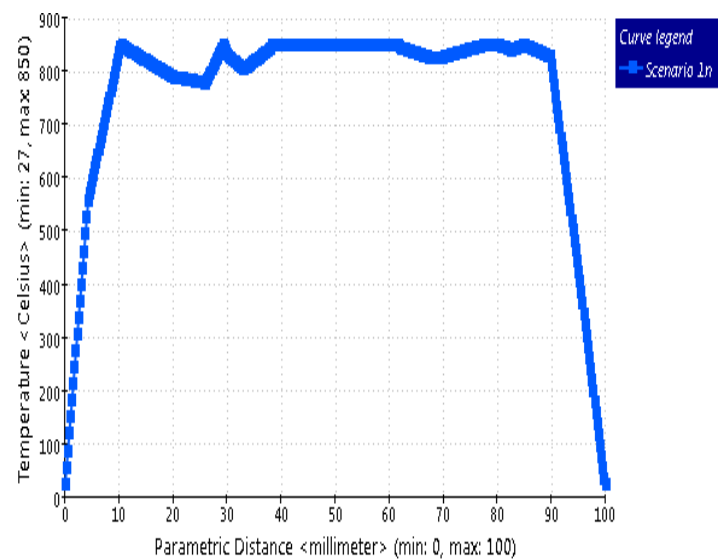

Fig. 6. Temperature Profile from CFDModel for the second pass

\section{MECHANICAL TESTS:}

\section{(I) Tensile Properties}

Some of the results obtained from the tensile test are presented in Table 2. The tensile behaviours of the tested materials under tensile are also graphically presented using the stress-strain curves in Figure 7.

\begin{tabular}{|l|c|c|c|c|}
\hline \multicolumn{1}{|c|}{ Specimens } & $\begin{array}{c}\text { Stress at } \\
\text { yield (MPa) }\end{array}$ & $\begin{array}{c}\text { Stress at peak } \\
\text { (MPa) }\end{array}$ & $\begin{array}{c}\text { Extension at } \\
\text { yield (mm) }\end{array}$ & $\begin{array}{c}\text { Energy at } \\
\text { yield (J) }\end{array}$ \\
\hline Untreated welded steel (UN) & 847.26 & 965.12 & 14.8 & 202.5 \\
\hline Annealed welded steel (AN) & 283.49 & 669.80 & 17.3 & 215.8 \\
\hline Normalized welded steel (N) & 272.55 & 714.06 & 15.4 & 231.3 \\
\hline $\begin{array}{l}\text { Quenched-hardened with water } \\
\text { welded steel (QHW) }\end{array}$ & 669.80 & 755.52 & 14.0 & 170.3 \\
\hline $\begin{array}{l}\text { Quenched-hardened with palm oil } \\
\text { welded steel (QHP) }\end{array}$ & 714.06 & 847.26 & 12.2 & 15.9 \\
\hline $\begin{array}{l}\text { Quenched-hardened with total oil } \\
\text { quartz 5000 welded steel (QHT }\end{array}$ & 755.52 & 919.16 & 13.7 & 14.7 \\
\hline $\begin{array}{l}\text { Quenched-hardened with ground } \\
\text { nut oil welded steel (QHG) }\end{array}$ & 283.75 & 898.16 & 13.4 & 13.7 \\
\hline
\end{tabular}

Table 2. Tensile properties of post weld heat-treated and untreated specimens

In Figure 7 below, variations of Tensile Stress (MPa) against Tensile Strain $(\mathrm{mm} / \mathrm{mm})$ for different conditions of quenching media are shown. The curve (Figure 7) reveals the structural loadability (loading bearing capability) of each of the tested materials, which is one of the most important material properties [18]. Three different regions (Elastic, Non-uniform plastic and Necking regions) with each region showing the uniqueness of the engineering materials behaviour are depicted in the result graphically. In multi-pass welds, weld metal in different locations experiences different thermal cycle, restraint conditions and strainhardening magnitude in each location. The difference in their locations is said to be responsible for the variation in the experiences [19]. 


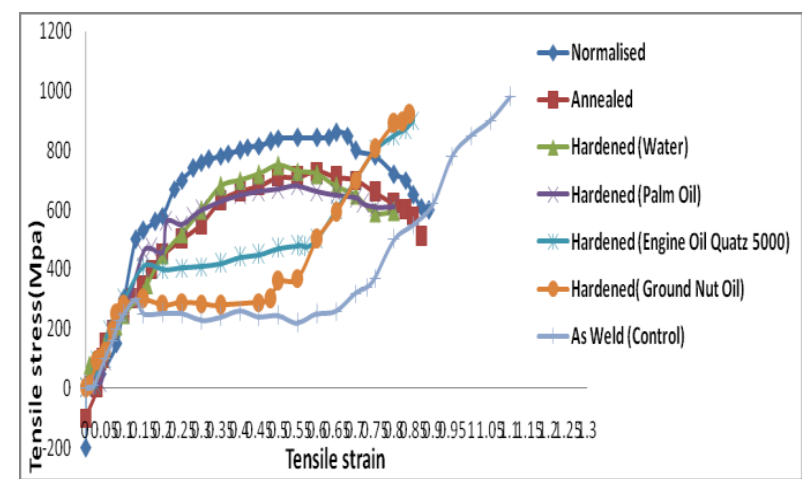

Fig. 7. Stress/Strain curves for thermal treated samples (quenched-hardened) and untreated sample of welded $0.165 \%$ low carbon steel

All mechanical properties of low carbon steels are significant when considering its ability to resist mechanical forces / loads. But in this study, the yield properties of the welded steel will be the main basis of the results' discussion due to its significant. Yield stress is the stress which produces a small amount of permanent deformation [20], which is mostly used for design in engineering practice. For a component to support a force successfully in service, high yield strength value is required, since it must not deform plastically while in use. Hence, yield strength is an important value use engineering structural design, since it is the amount of a stress at which plastic deformation is noticeable and significant [21]. The yield strength of the weld metal has a significant effect on the final hoop stress in the weld zone and its vicinity [19].

The studied steel recorded yield stress in descending order of untreated specimen (847.26 MPa), quench-hardened specimen with total quartz 5000 (755.52 MPa), quench-hardened specimen with palm oil (714.06 MPa), quench-hardened specimen with water (669.80 MPa), quench-hardened specimen with groundnut oil (283.75 MPa), annealed (283.49 MPa), and normalized (272.55 MPa). This shows that all PWHT processes reduced the ability of the steel resist deformation as results of force applied, since yield stress increases as the amount of stress a metal can support without deforming increases [22]. The analysis of the experimental results revealed that the thermal treatment processes reduced the stress of the low carbon steel at yield point. Thus, any accumulated gas in resulted blow-hole as result of welding process and stresses in the steel material during welding process were reduced significantly. Though yield strength is unimportant for a ductile material selection and application, because too much plastic deformation takes place before it is reached [21].

The noticeable differences in the yield strength of the tested steel can be attributed to the difference in the process of heat treatment. Differences in yield strength arise from different heat treatment processes rather than composition of the material [21].

The stress of welded steel at peak (Ultimate tensile strength) also decreased in order of untreated specimen (965.12 MPa), quench-hardened specimen with total oil quartz 5000 (919.16 MPa), quench-hardened specimen with groundnut oil (898.16 MPa), quench-hardened specimen with palm oil (847.26 MPa), quenchhardened specimen with water (755.5 MPa), normalized (714.06 MPa) and lastly annealed (669.86 $\mathrm{MPa}$ ). These are the maximum amounts of stresses that the tested samples can support before they deform totally. At peak, the ultimate tensile strength of the welded steel was reduced as result of PWHT.

The extension of the steel samples at yield is the extent of their being plastically deformed at the yield point without failure. The result (Table 2) showed that the PWHT processes affected the values of the steels' ductility. The ductility of the specimens were in descending order of normalized $(15.4 \mathrm{~mm})$, annealed $(17.3 \mathrm{~mm})$, untreated specimen $(14.8 \mathrm{~mm})$, quenchhardened specimen with water $(14.0 \mathrm{~mm})$, quenchhardened specimen with total oil quartz 5000 (13.7 $\mathrm{mm}$ ), quench-hardened specimen with groundnut oil (13.4 $\mathrm{mm})$, and quench-hardened specimen with palm oil $(12.2 \mathrm{~mm})$. The level of safety in using the steel in service is also revealed. Ductile material will deform and also increase in its strength through work hardening, once the load on one of the parts increases over the yield stress [23]. Thus, the component will not fail catastrophically and abruptly like that of material with very low ductility.

The absorb shocking load (toughness) ability of the studied steel at yield is also expressed with the energy values at yield in descending order of normalized (231.3 J), annealed (215.8 J), untreated specimen (202.5J), quench-hardened specimen with water (170.3 $\mathrm{J})$, quench-hardened specimen with palm oil (15.9 J), quench-hardened specimen with total quartz 5000 (14.7 $\mathrm{J}$ ) and quench-hardened specimen with groundnut oil $(13.7 \mathrm{~J})$. The result shows the ability of the tested materials to absorb energy and plastically deform without fracturing.

\section{(II)Hardness properties}

The hardness of the test-pieces was tested at welded pool and HAZ. The variations of hardness values at welded pool and heat affected zone (HAZ) for welded specimens are shown in Figure 8.

At welded pool zone, the average hardness values of all heat-treated specimens were lower than that of untreated specimen. The steel hardness value at the region was in descending order of Untreated (106.86 BHN), Quenched-hardened with total engine oil (100.77 BHN), Quenched-hardened with ground nut oil (99.87 BHN), Quenched-hardened with palm oil 89.7 BHN), Quenched-hardened with water (84.06 BHN), Normalized (69.84 BHN) and Annealed (62.11 BHN). This shows that normalizing and annealing post-weld heat treatments resulted into lower strengths of the low carbon steel at heat affected zone and at the welded pool region. Normally, the decrease in hardness value of the heat-treated specimens when compared with that of untreated specimen was expected for normalizing and annealing thermal treatment processes.

Meanwhile at the heat affected zone (HAZ), the quench- hardened specimens (martensite) had average hardness values of 133.73 BHN, 125.64 BHN, 123.99 BHN and 88.13 BHN for Quatz 5000 Engine oil, Ground nut oil, Water and Palm oil media 
respectively. Untreated specimen had 88.13 BHN average hardness value at heat affected zone. This signifies that quench-hardening improved the strength of low carbon steel at heat affected zone.

Hardness and tensile strength are indicators of a metal's resistance to plastic deformation [23].

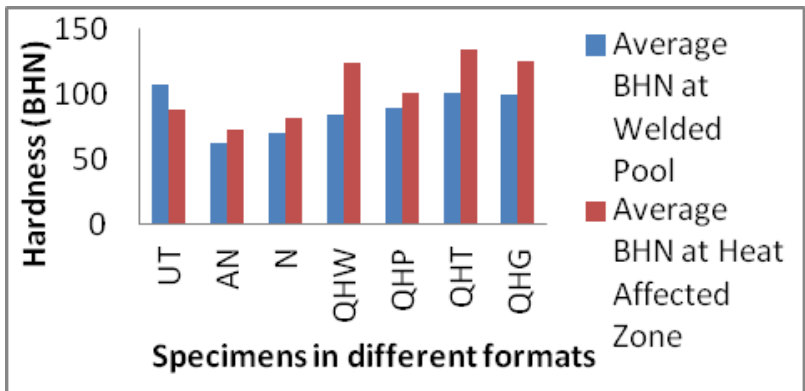

Fig. 8. The average Brinell hardness of the welded steel in different formats at both welded pool and heat affected zone..

\section{Impact Test}

Figure shows variations of impact values at heat affected zone (HAZ) for welded specimens.These results indicated the impact values for heat affected zone (HAZ) for all the specimens. The annealed specimens had the highest impact average value of 45.5 $\mathrm{J}$, followed by normalized specimens with average value of $42.96 \mathrm{~J}$; while the quenched-hardened specimens (quenched in different media) had the lowest average values of $35.8,36.65,37.75,39.1 \mathrm{~J}$ as shown in Figure 7. Meanwhile, untreated welded specimens had average value of $41.55 \mathrm{~J}$. The results show that annealed and normalised as thermal treatment processes improved the ability of the steel to absorb shock before fracture. This is an indication that untreated welded specimens (at the welded zone) exhibited a poor toughness compared to annealed and normalized specimens. But as the TTP duration time is increased, the toughness level of the HAZ region of welded specimens also increased.

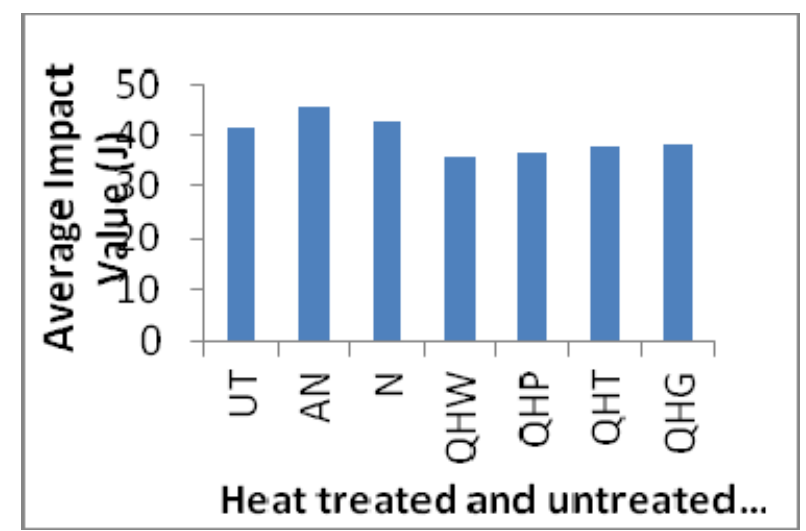

Fig. 9. Impact test result of heat affected zone (HAZ)

\section{Fatigue Test}

Fatigue testing was to ascertain the actual load the heat treated low carbon steel could withstand before failure in service. Upon the application of bending load the fatigue strength of each sample conditions for $0.165 \%$ carbon steel are as shown in Figure 8. The average number of cycles obtained for each material condition could be deduced in the Figure. The fatigue strength of untreated welded samples declined to 284 MPa from $2840 \mathrm{MPa}$ resulting into failure at the $5^{\text {th }}$ cycle. When compared with the heat-treated samples, higher fatigue strength of $386 \mathrm{MPa}$ was achieved with the normalized samples at 5.8 cycles, followed by annealed samples that exhibited fatigue strength value of $273.8 \mathrm{MPa}$ at 6.6 cycles. It was also noted that the average highest number of cycles (13.9) was obtained with untreated welded samples. Meanwhile, the quench-hardened (Water) samples gave the least number of cycles (1.8). All the samples exhibited considerable amount of deformation within relatively number of cycle. The result therefore showed that for the four material conditions (annealing, normalizing, quenching and non- heat treated), the failure mechanism was by low-cycle fatigue.

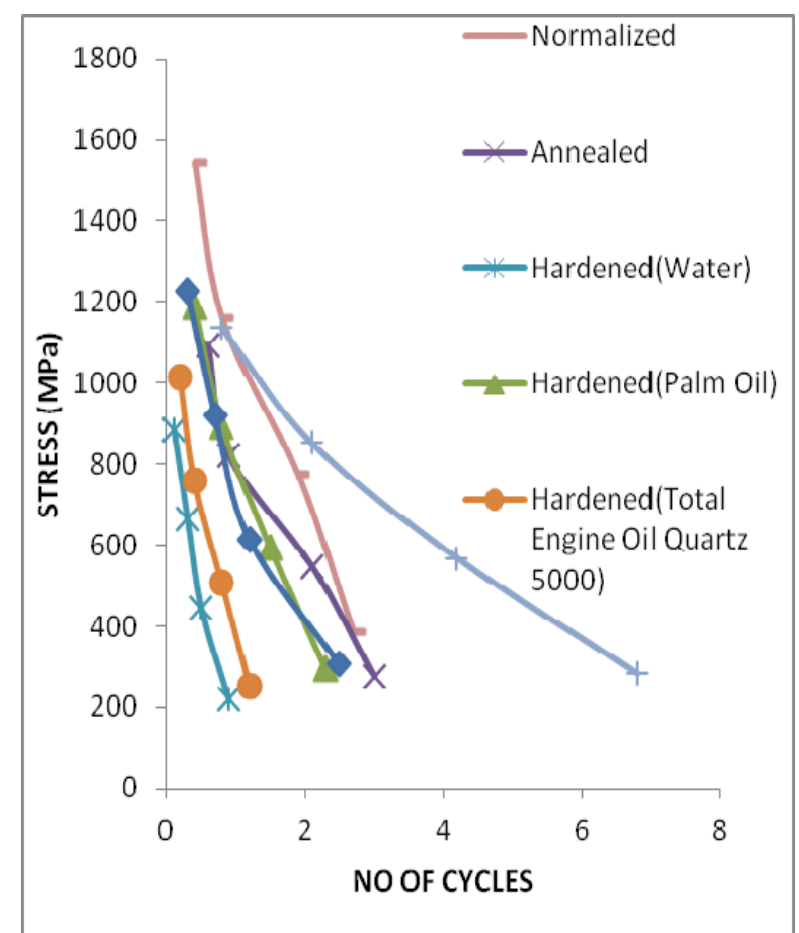

Fig. 10. Stress against number of Cycles for TTP Low Carbon Steel Specimens

\section{Microstructural analysis}

The microstructures of untreated welded (Asreceived weld) specimen and Post weld heat treated specimens were presented in Plates 6 to 12 . Microstructure of the samples varied from one another. According to TTP [21], "hardening and tempering heattreating process for AISI 4140 will give rise to microstructural change in the steel”.

The microstructure of the untreated welded carbon steel sample revealed ferrite in the grain boundaries of the acicular pearlite grains. This can be described as having a ferrite-austenite duplex phase (Plates 6). Annealing (a post weld heat treatment process) affected the spatial distribution of ferrite at the grain boundaries. Due to oxidation at the metal surface during PWHT, scales were formed as observed to be present in ferrite in Plates 7. Normalizing PWHT gave a uniform large grained structure of ferrite and pearlite with fine 
grained (Plates 8). Through quench-hardening PWHT processes in various selected media (Water, Palm oil, Engine oil quatz 5000 and Groundnut oil), the presence of scales was revealed and more widely distributed on the metal surface and highly dispersed ferrite (Plates 9 to Plates 12).

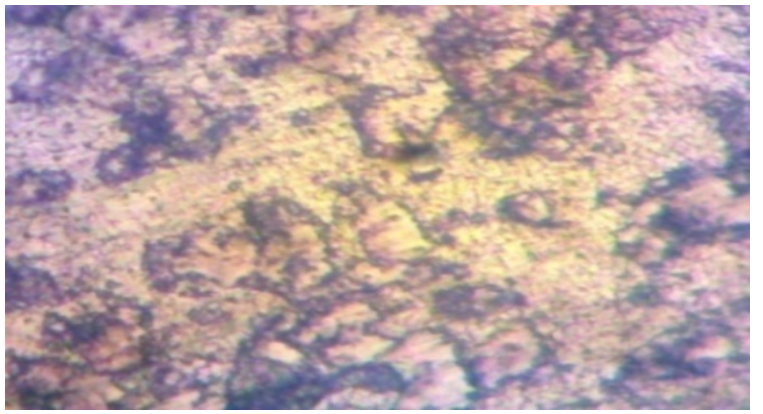

(i)

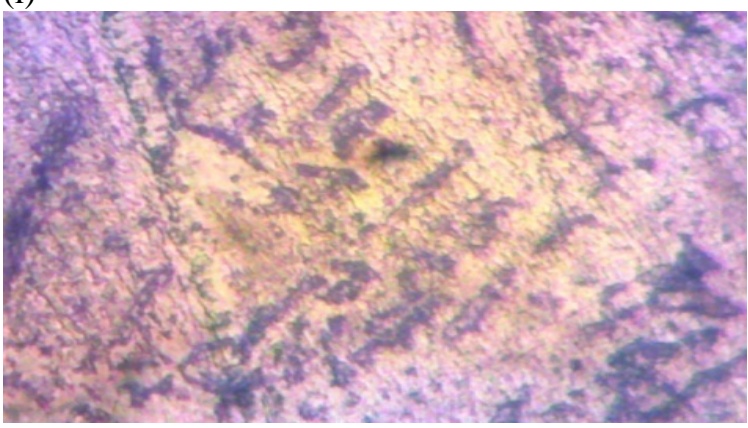

(ii)

Plate 6. Microstructural of Untreated (As-weld) specimens, (i) Welded pool, (ii) HAZ. 40 x 16

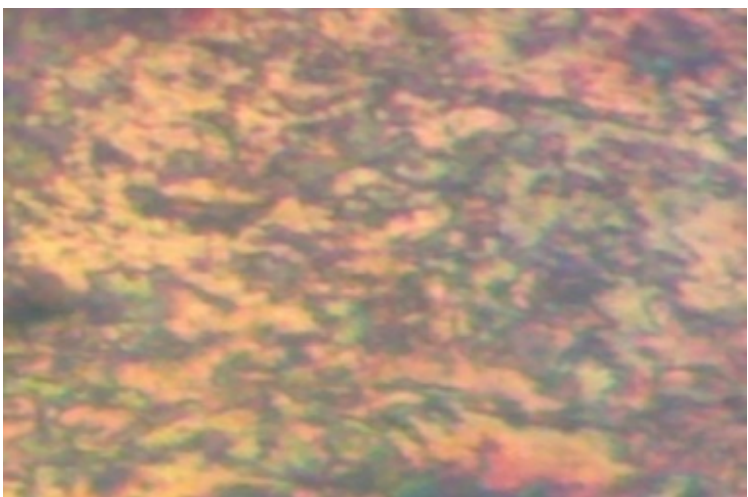

(i)

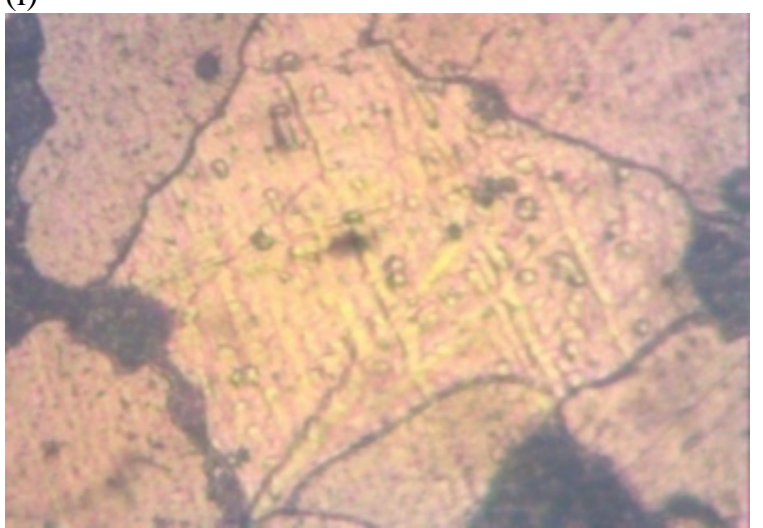

(ii)

Plate 7. Microstructural of annealed specimens, (i) Welded pool, (ii) HAZ. 40x16

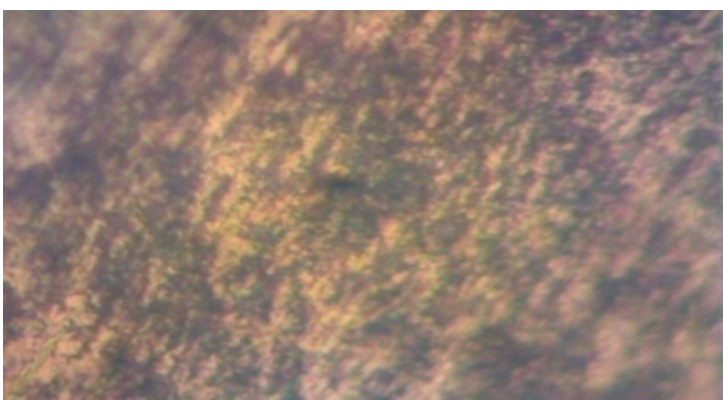

(i)

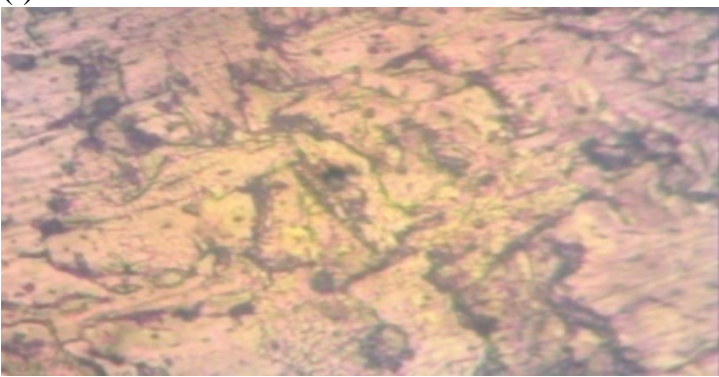

(ii)

Plate 8. Microstructural of normalized specimens, (i) Welded pool, (ii) HAZ. 40x16

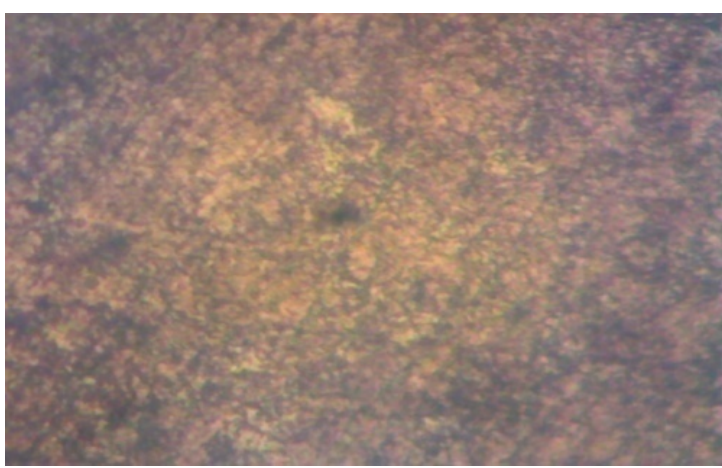

(i)

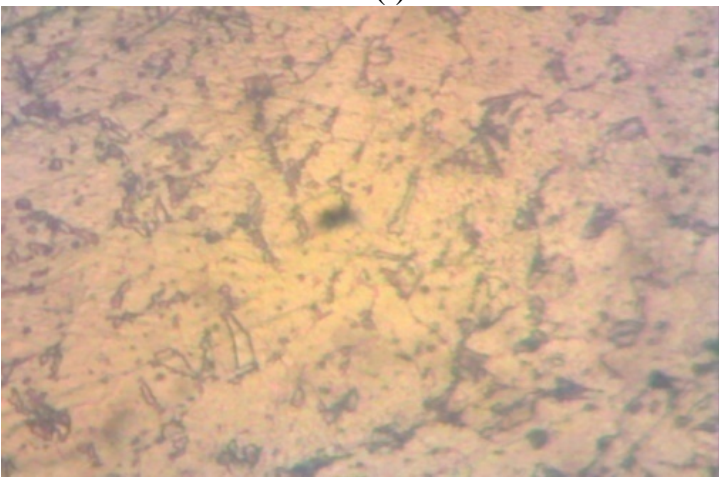

(ii)

Plate 9. Microstructural of Water quenched specimens, (i) Welded pool, (ii) HAZ. 40x16

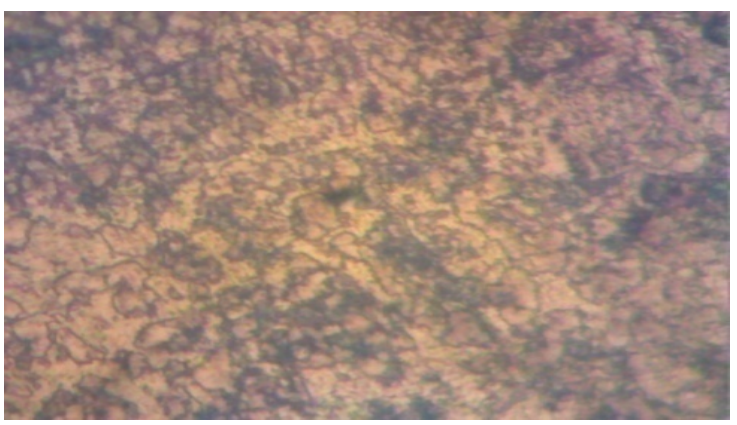

(i) 


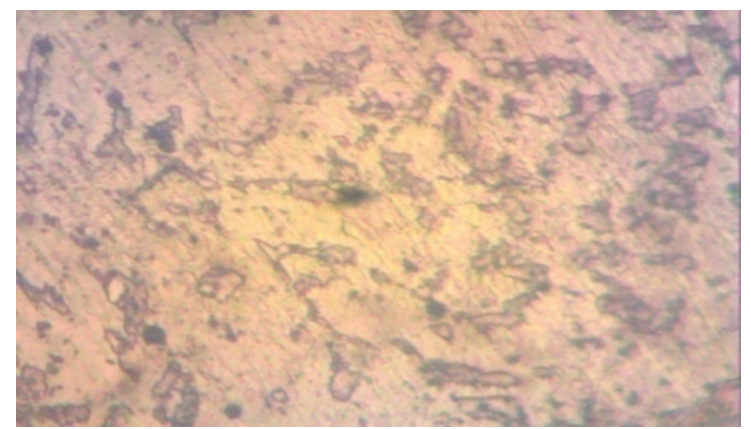

(ii)

Plate 10. Microstructural of Palm oil quenched specimens, (i) Welded pool, (ii) HAZ. 40x16

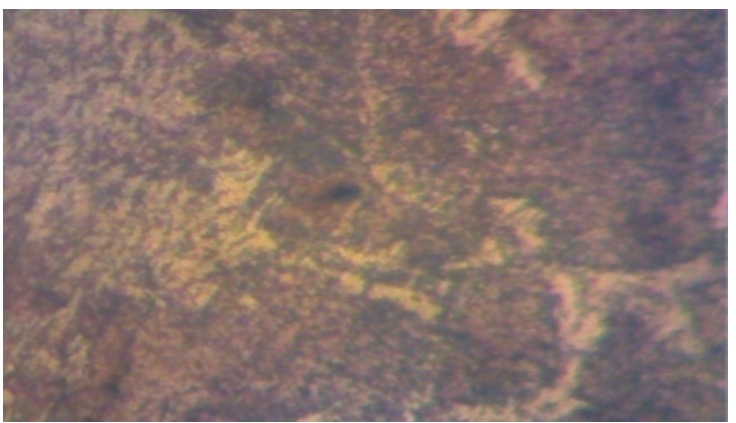

(i)

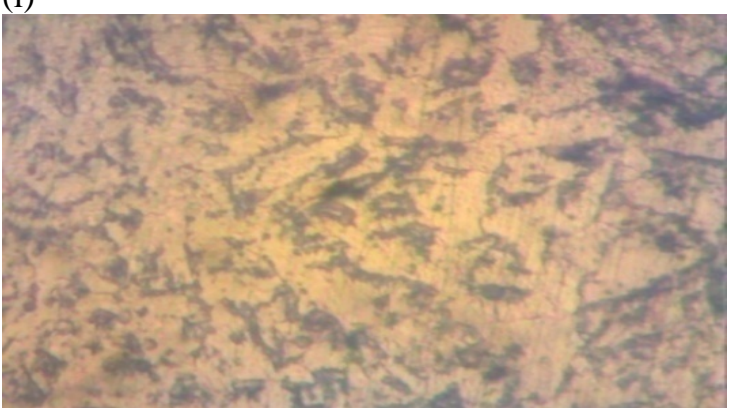

(ii)

Plate 11. Microstructural of Quartz 5000 Total Engine oil quenched specimens, (i) Welded pool, (ii) HAZ. 40x16

The observed variations in the microstructure and mechanical properties of the samples can be attributed the differences in heat treating parameters, majorly mode of cooling after heat treatment. Quenching media is an important parameter in heat treatment that affects the microstructure, grain size and eventually the mechanical parts of the steel [23].

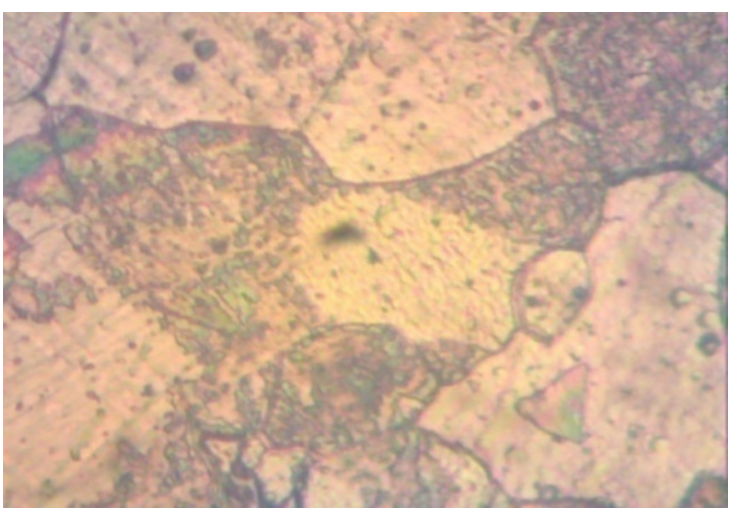

(i)

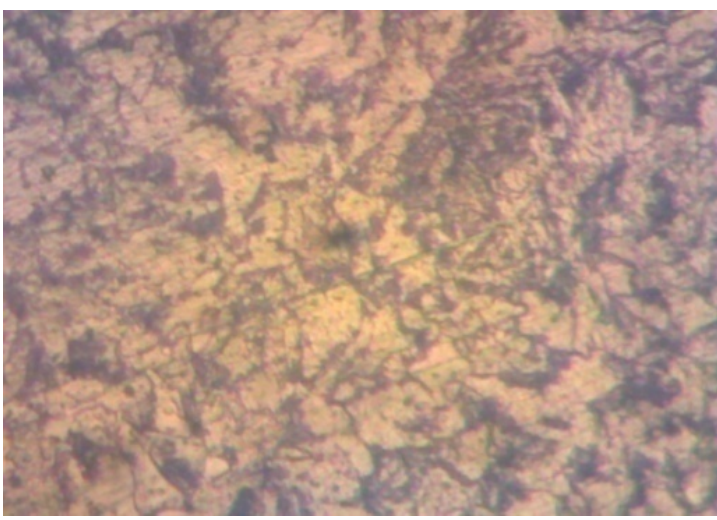

(ii)

Plate 12. Microstructural of Ground nut oil quenched specimens, (i) Welded pool (ii) HAZ. 40x16

Differential microstructures resulted from the different heat treating parameters used by the heat treatment providers also led to difference in yield strength [23]. The heat treating parameters include austenitizing temperature, soaking time, quenching media and tempering temperature and time.

\section{CONCLUSION}

From the study the following conclusions were derived:

(i). The CFD model revealed real welding conditions temperature profiles and microstructure showing $\mathrm{XY}$, YZ and ZX planes of the welded steel. This enhances better understanding of the real welding conditions that may assist to proffer solution to likely structural failure that may arise in the welding joints as result of welding residual stress

(ii) The PWHT processes reduced the stress of the low carbon steel at yield point.

(iii) Annealing and normalising as PWHT processes enhanced the steels' ductility and the toughness, while quench-hardening processes reduced the properties

(iv) At the heat affected zone and welded pool, annealing and normalising PWHT processes reduced the hardness of the steel, which implies that the steels' strengths at the points were enhanced. Though, quenchhardened was found to improve the steels' hardness at HAZ. Meanwhile, all PWHT processes reduced the steels' hardness at the welded pool.

(v) The failure mechanism in the steel by fatigue was by low-cycle fatigue.

(vi) Butt-welded annealed and normalized low carbon steel specimens tend to be more resilient to failures at welded joints. This is because of their higher tensile stress at yield, tensile strain at yield, load at yield and Energy at break; and lower hardness value at welded zone and at the HAZ. Hence, TTP techniques significantly improves the mechanical property of buttwelded annealed, normalized low carbon steel. (vii) Better quality mechanical behaviour of welded low carbon steel is elicited by post-weld normalizing and annealing TTP. 


\section{REFERENCES}

[1] Ejilah, R. I., Onuh, E.I., and Datau, S.: A Study of the effect of post weld heat treatment (ttp) on the torsional behavoir of low carbon steel, NIMechE 22nd International conference, pp.13, 2009.

[2] Oloabi, A.G. and Hashmi, M. S. J.: The effect of post weld teat treatment on mechanical properties and residual stresses mapping in welded structural steel, Journal of Material Processing Technology, Vol.55,issue 2, pp.117-122,1995.

[3] Dean, D. and Hidekazu, M.: Numerical simulation of temperature field and residual stress in multi-passwelds in stainless steel pipe and comparison with experimental measurement. Computational Material Science, Vol. 37, pp 269277, 2006.

[4] Atlas: Common culprits - 4 factors leading to structural failure. Atlas Foundation Co. Retrieved from www.atlasfoundations.com/commonculprits-4factors-leading-structural-failure/, accessed October 18, 2016.

[5] Bright Hub Engineering: Structural Failure. Retrieved from www.brighthubengineering.com/buildingdesign/52749-structuralfailure/, accessed October 18, 2016.

[6] Merchant, S. Y.: A review of effect of welding and post weld heat treatment on microstructure and mechanical properties of grade 91 steel, International Journal of Research in Engineering and Technology, Vol.04, March, pp 574-580, 2015.

[7] Daramola, O. O., Adewuyi, B. O. and Oladele, I. O. (2010): Effects of Heat Treatment on the Mechanical Properties of Rolled Medium Carbon Steel,Journal of Minerals \& Materials Characterization \& Engineering, Vol. 9, No.8, pp.693-708, 2010.

[8] Chen L.: Effect of TTP temperature on mechanical properties of High-Cr ferritic heatresistant steel weld metal. Welding in the World, Vol.56, pp 1-2, January-February, 2012.

[9] Davies A.C., (1996): Welding, New york, 10th Edition,Cambridge University Pres, pp.343-377.

[10] The New International Webster's Comprehensive Dictionary of the English Language, (2010) : Deluxe Encyclopedic Edition, Typhoon Media Corporation, USA, pp.583.

[11] Senthilkumar, T. and Ajiboye, T.K. (2012): Effect of heat treatment processes on the mechanical properties of medium carbon steel, Journal of Minerals and Materials Characterization and Engineering 11(2) pp. 143-52.

[12] Devinder,P.S., Mithlesh,S. and Jaspal,S.G., (2013): Effect of Post Weld Heat Treatment on the Impact Toughness and Microstructural Property of P-91 Steel Weldment, Vol. 3, Issue 2, International Journal of Research in Mechanical Engineering \& Technology, pp 216-219. http://www.ijrmet.com/vol32/devinder.pdf

[13] Joseph, O. O. and Alo, F. I.: An Assessment of the Microstructure and Mechanical Propertiesof
0.26\% Low Carbon Steel under Different Cooling Media: Analysis by one-way ANOVA, Industrial Engineering Letters, Vol.4,No.7, pp 39-43, 2014.

[14] Shuaib-Babata, Y. L. and Adewuyi, R. A.: Simulation of Heat Affected Zone (HAZ) in MultiPass Welds in Low Carbon Steel. Book of Proceedings of the 15th Annual International Nigerian Materials Congress (NIMACON), pp 642-647, 2016.

[15] BS 240: Method for Brinell test and for verification of Brinell hardness machine. British standards Institution, 1986

[16] ASTM E10-15a: Standard test method of Brinell hardness of metallic materials. ASTM International, West Conshohocken, PA, 2015.

[17] Shuaib-Babata \& Adewuyi:.Effects of Thermal Treatment Processes (TTP) on the Tensile Properties of $0.165 \%$ Carbon Steel. FUOYE Journal of Engineering and Technology, Volume 1, Issue 1, pp 15-19, 2016b.

[18] Rime: Stress-Strain curve. Retrieved from: http://www.rime.de/en/101/stress-strain-curve/. Accessed March 8, 2017.

[19] Deng, D., Murakawa, H. and Liang, W.: Numerical and experimentation investigations on welding residuals stress in multi-passwelds buttwelded austenitic stainless steel pipe. Computational Material Science, Vol. 42, pp 234244. 2008, Available online at www.sciencedirect.com

[20] Dieter, G. E. (1988). Mechanical Metallurgy, SI Metric Edition, McGraw-Hill Book Company (UK) Ltd, London.

[21] TPP (2017). Yield strength and heat treatment, Available from http://www.tppinfo.com/defect_analysis/yiel d_strength.html

[22] Industrial Metallurgists (2017). The difference between strength and toughness. http://www.imetllc.com/training-article/strengthtoughness, 27/2/2017

[23] Quora (2017). Why is ductility important in some metals? https://www.quora.com/Why-is-ductilityimportant-in-some-metals

Authors: Senior Lecturer, Dr. Yusuf Lanre ShuaibBabata, Department of Materials and Metallurgical Engineering, University of Ilorin, Ilorin, Nigeria. $+2348033945977$

Senior Engineer, M.Eng, R.Eng,Reuben Adebare Adewuyi, Olusegun Obasanjo Centre for Engineering Innovation, The Federal Polytechnic, Ado-Ekiti, Nigeria. +2348038458613

Associate Professor, Dr. Jacob O. Aweda Department of Mechanical Engineering, University of Ilorin, Ilorin, Nigeria.

E-Mail: sylbabata@gmail.com/shuaib-

babata.yl@unilorin.edu.ng reuben1178@yahoo.com 